\title{
Investigating the Effectiveness of the Maritime Regulatory Regime to Address a Socially Responsible Shipping Industry: A Content Analysis Study
}

\author{
Ioannis Fasoulis ${ }^{1,2}$ \\ ${ }^{1}$ Maritime Professional, Safety and Quality Systems Auditor, Athens, Greece \\ ${ }^{2}$ Department of Naval Architecture, Ocean and Marine Engineering, University of Strathclyde, 100 Montrose St, Glasgow G4 \\ OLZ, UK
}

Corresponding Author Email: giannisfasoulis@yahoo.gr

https://doi.org/10.18280/ijsdp.160403

Received: 4 April 2021

Accepted: 21 July 2021

\section{Keywords:}

maritime regulatory regime, CSR, sustainable shipping, ISO 26000 standard, compliance

\begin{abstract}
The introduction of Sustainable Development Goals (SDGs), in 2015, has transformed the approach of public and private entities to address environmental, social and economic challenges. As result, new governance and management insights are sought, among them corporate social responsibility (CSR), which is increasingly seen as a self-regulating means to help organizations meet multifaceted challenges. With regard to shipping, global developments have called for a blueprint to facilitate industry's transition to a more sustainable pathway. However, CSR applicability in the maritime business is relatively recent and has been mainly viewed as a voluntary and beyond regulatory compliance notion. Among these shifts, this study explores the effectiveness and extent to which the maritime regulatory regime has addressed CSR topics. A case study strategy and content analysis method is employed. In turn, ISO 26000 social responsibility standard employed as the guiding paradigm to identify applicability of CSR norms within selected maritime legislation. Findings revealed a satisfactory coverage by the maritime regime of CSR issues falling under the scope of human rights, labor, the environment and organizational governance subjects. Though, it seemed to lag behind in subjects situated within the array of fair operating practices, consumer treatment and community involvement.
\end{abstract}

\section{INTRODUCTION}

Corporate social responsibility (CSR) and sustainable development refer to concepts, which have long since appeared and spread in the business setting [1]. Taking a closer look and reviewing the current legal, regulatory and policy frameworks, but also how they have evolved over the years, it is clear that CSR and sustainable development principles often supplement each other. In addition, they have now penetrated all forms and levels of public governance and business planning [2]. First, the term of sustainable development gained a significant momentum after the 1987 World Commission on Environment and Development, known as the Brundtland Commission [3]. This United Nations (UN) declaration achieved, for the first time, a generally accepted sustainable development definition as: "the development that meets the needs of the present without compromising the ability of future generations to meet their own needs" [4]. Since then, the term has been used repeatedly in government, academic, and business literature and has been seen identical to the establishment of a policy framework to control and minimize the negative impact of business process on the environment [5]. Then, a significant development and transformation of this term was made by John Elkington, in 1994, who credits the approach to the so called triple bottom line approximation [6]. Thereinafter, in modern times, this evolution of the sustainable development term in such integrated form has found support in the 2015 United Nations 2030 Agenda, and incorporated 17
Sustainable Development Goals (SDGs) [7]. Thus, nowadays sustainable development has been treated as a cohesive concept sharing social, economic and environmental extents [8].

On the other hand, corporate social responsibility has followed its own progression path for about 50 years [9]. Yet, it should be acknowledged that its theoretical background and driving forces have been different than those of sustainable development [10]. Reviewing the relevant literature, we see that CSR was initially linked to the effort of organizations to address social issues arising from business activities. Accordingly, their primal focus was placed on managing stakeholders, along with balancing and addressing their expectations arising from the interaction of business and social fabric [11-13]. Afterwards, the term of CSR evolved and included further activities such as, charities, donations, ethical behavior, labour issues, educational endeavors, ecological programs, human rights and consumer matters as generated among companies and communities dealings [14-16]. However, since 2000s, there has been a tendency to link corporate social responsibility and sustainable development. Evidently, in the midst of such evolving and strengthened relationship, CSR has been established as a business model used to assist businesses to achieve sustainable development objectives [17-19].

The shipping industry is the link in the global supply chain that contributes greatly to the facilitation and uninterrupted flow of world trade. The fact that almost $90 \%$ of the world's 
goods are transported by sea demonstrates the efficiency and convenience of this means of transport, especially when it comes to mass transportation of products [20]. In addition, studies have ranked shipping as one of the most environmental friendly and safe means of transport, always compared to the volume of goods it carries [21]. However, concerns have been repeatedly raised over time for the need to regulate shipping eliminating, thus, inherent risks posed to the environment and seafarers' lives [22]. Furthermore, when it comes to the attempt to legislate the shipping industry to reduce these risks, such venture has been further complicated by the fact that ships are mobile assets that are constantly changing homelands, oceans and ports around the world [23-25]. Coinciding with the conventional problems of shipping, the current pressures for environmental excellence, exercised by the new UN framework of SDGs, have turned shipping to alternative management models to meet regulatory challenges [26].

The International Maritime Organization (IMO) has undertaken the difficult role of generating regulations and shaping the maritime regulatory framework worldwide [27]. Since 1948, it has managed to create a robust maritime regulatory regime including a plethora of safety, environmental, security and labour regulations followed globally by the shipping industry [27-29]. Amid the abundance of maritime statutory regulations governing aforementioned maritime issues, this article explores whether normative developments, as reflected in the International Safety Management (ISM) Code, the International Ship and Port Facility Security (ISPS) Code and the Maritime Labour 2006 (MLC) Convention, have the potential to address core CSR themes. Exploration of this area becomes even more stimulating in the light of the application of United Nations Sustainable Development Goals in shipping and the encouraging role that CSR can play in facilitating such transitions [30, 31]. To better understand and empirically explore these interactions, the following research question has been formulated:

- How effectively, or in other words, to what extent has the current maritime regulatory regime addressed CSR issues?

Hence, such inquiry is explored by a carefully designed case study strategy and applied content analysis method, framed by a qualitative methodological approach. NVivo qualitative software aids are used to facilitate data analysis and obtain results. The paper is structured as follows. First, to provide an analytical background for discussion, a review of the application of CSR and sustainable development concepts in shipping is first presented. Main features of the nominated maritime regulatory framework (ISM, ISPS, MLC 2006), and employed ISO 26000 CSR paradigm are analyzed, along with justification for such regime selection. Then, section 3 describes the methodology followed in our study. The remainder of the paper presents the results (section 4), key discussion points (section 5) and concluding remarks (section $6)$.

\section{BACKGROUND AND STUDY FRAMEWORK}

\subsection{CSR and sustainable development in the shipping context}

The 17 Sustainable Development Goals, adopted by United
Nations, on 25 September 2015, included specific commitments and obligations for business in areas such as education, water conservation, gender quality, innovation and infrastructure, clean energy use, poverty alleviation, climate change action, responsible production and consumption etc. [32]. The IMO, through the adoption of a series of policy documents and action plans, has explicitly recognized and committed to achieve a sustainable transport sector supporting, thus, global environmental efforts and facilitating world trade and sustainability of global economy [33-35]. In that sense, a detailed investigation has been initiated by the Organization with the aim to highlight the individual linkages between SDGs and maritime transport indicating, thereby, how shipping can contribute to each target $[30,36]$. Many of the SDGs found to be related to IMO work such as, SDG 13 on climate action, SDG 14 on the conservation and sustainable use of the oceans, seas and marine resources for sustainable development, and SDGs 9 on infrastructure investment and innovation. As result, several existing but new regulatory measures have been put in place to provide guidance to flags states in adapting their national legislation on issues related to elimination of air pollution and Sulphur emissions from ships, reduction of marine plastic litter, preservation of sea areas with ecological, socio-economic or scientific significance and formation of global partnerships to support developing countries [27, 36, 37].

In the field of corporate social responsibility the situation in the shipping field appears somewhat premature $[30,38]$. And this is not because shipping companies have not embraced CSR into their management systems. On the contrary, lately, more and more shipping companies are have become aware and adopted a policy of social responsibility recognizing, thus, its long-term benefits [39-41]. However, the point is that at policy and regulatory level there is not an integrated and universal regime to prescribe and urge maritime organizations to implement CSR principles [42-44]. Nevertheless, we should not overlook that the plethora of maritime regulations could possibly embrace many of those elements that make up CSR concept such as, labour contracts, environmental protection, occupational safety, ethics and corporate governance issue. Though, no explicit provision is made in the relevant maritime directives or treaties regarding the mandatory implementation of a CSR framework in shipping. Yet, it is worth mentioning that, in the midst of all these changes in the field of sustainable development, IMO, through a statement made by its Secretary General, Mr. Koji Sekimizu, has pointed out the need to adopt corporate social responsibility. Hence, CSR could greatly assist maritime actors if used as a management model to integrate the threefold of sustainable development, thus, raising industry's contribution to SDGs [45]

\subsection{Emergence of ISO 26000 standard and opportunities for shipping}

ISO 26000 social responsibility standard was first introduced on 1 November 2010 , by the International Organization for Standardization (ISO), and aimed at providing guidance to business and, generally, all organizations, either private or public, and regardless their size and scope of operation, seeking to operate in a socially responsible manner [46]. According to ISO 26000 principles and operating guidelines, organizations should consider the impacts from their decisions and activities on the environment, society and the economy and, hence, take actions to balance 
and mitigate adverse impacts [47]. Based on this philosophy, ISO 26000 has been also seen as a first class opportunity to assist companies to increase their contribution to UN SDGs, something that is explicitly stated in its textual guidelines [48]. Moreover, unlike other social and environmental standards, for instance, SA8000 Standard, AA1000, ISO 14001 on environmental management and ISO 9001 on quality management, ISO 26000 is not intended for certification and maintains a voluntary nature $[49,50]$. With regard to its content, this particular social responsibility model is quite comprehensive and lengthy, with its principal guidelines being summarized under the following seven core themes/subjects:

Organizational governance;

Human rights;

Labour practices;

The environment;

Fair operating practices;

Consumer issues; and

Community involvement and development [51].

What led us to consider ISO 26000 as a reference point and benchmark of corporate social responsibility in this study, lies, firstly, in the remarkable completeness and versatility of included topics, along with its broadened approach to social responsibility notion. Thereby, organizations are called upon to consider the issues that fall within the above core subjects and assess their relevance to a variety of matters related to stakeholders, company's objectives, governance structure, community surroundings and several other human, safety and environmental aspects of their organizational activities [5254]. Thus, compared to other social responsibility templates, ISO 26000 includes perhaps the most extensive range of issues an organization may encounter and, furthermore, is projected, from the ground up, to contribute to sustainable development $[55,56]$. In addition, its advisory and non-requirement for certification nature is highly aligned with the belief of many shipping companies that CSR is a voluntary concept, which can be adequately implemented without creating another mandatory legal framework [26, 42]. As a matter of fact, all these features make ISO 26000 a truly remarkable object of study in determining the extent to which the maritime regulatory system is sufficient to fulfill its principles.

\subsection{Delimiting the maritime regulatory ground and case study context}

From its earliest times, merchant shipping has been considered one of the most heavily regulated industries [57]. Although maritime transport has been considered among the safest and environmental friendliest transport modes, the inherently hazardous features of seaborne transport, namely, the harsh nature of the sea environment, has forced the international community to engage and put the industry under a strict regulatory framework [57-59]. As mentioned above, the International Maritime Organization has established a plethora of mandatory international maritime regulations concerning the construction, design, navigation, environmental protection, manning, occupational safety, and security of merchant shipping, which Flag Administrations have incorporated and implemented through their national legislation $[60,61]$. Similar to IMO, the International Labor Organization (ILO) refers to another pillar and collaborator in safeguarding maritime labour issues [62, 63]. However, in our attempt to explore whether the statutory maritime regulatory framework is sufficient to address CSR issues nowadays, we need to narrow our research field to those maritime regulations that correlate to the spirit and scope of CSR. Thus, among the numerous regulatory instruments seeking to establish construction, equipment and operation standards of ships, we delimit our research scope to those maritime regulations that arrange for social, environmental, safety, security and labour issues, from a managerial and process setting angle.

However, leaving out of the study scope important pillars of maritime regulations such as, the International Convention for the Safety of Life at Sea (SOLAS) or the International Convention for the Prevention of Pollution from Ships (MARPOL), could possibly raise some criticism. In that respect, it is stressed once more that the rationale that underpins this decision lies on the fact that those, along with other similar technically oriented regulatory instruments, are principally concerned with setting construction, design and equipment standards for merchant ships, that surely fall out of the CSR range. Hence, we delineated the case study context to the selection of those maritime regulations with a view of providing an international standard or means of a structured and documented management system and processes to facilitate decision-making and risk management within the organization. In that sense, the regulatory instruments that mostly meet these criteria and suit present research scope assumed to be the ISM Code, the ISPS Code and the MLC Convention, $2006[62,64,65]$. One could contend though that dimensions and obligations under these instruments vary, since they deal with multiple issues such as, security and safety of ships, pollution prevention, living and working conditions and social rights for seafarers. However, compared to the rest of statutory maritime regulations left aside, it is argued that they fulfill our earlier set criteria as they share a common distinctive feature $[66,67]$. In essence, such feature lies in urging shipping companies to ensure the safe, social and environmental responsible functioning of their organization, not solely through exhaustive technical and construction guidelines, but through the establishment of policies and procedures that take into account several other cultural, anthropocentric and societal parameters $[68,69]$.

\section{METHODOLOGY}

Choice of the research methodology greatly depends on the nature of the research problem and type of questions formulated to fill identified gap. To be adequately addressed, research problems require certain approaches to be adopted thus obliging specific plans and procedures to be charted [70]. In social studies, it is customary for the majority of surveys to be framed by either a qualitative, quantitative or mixed method approach. Qualitative studies seek to understand the research problem in a real life context. Hence, the research process builds inductively during the course of inquiry thus allowing the researcher to flexibly move from narrow to general assumptions. On the other hand, quantitative analysis involves large numerical data using statistical procedures to test relationships among variables. Accordingly, a deductive reasoning is embraced thus building on extensive literature reviews and resulting to the formulation of theories to be tested. Thirdly, mixed methodological studies systematically integrate quantitative and qualitative data providing a more spherical viewpoint of the research problem [71]. Equally important to a research approach selection is the research strategy, namely, the detailed plot to be followed in planning, 
executing, and monitoring the study course, including the data collection and analysis methods [70, 72]. Obviously, formulating a research strategy depends on the adopted research approach and may include questionnaire surveys, interviews, case studies, observations, experimental research etc. Consequently, research strategy specification determines the way in which data will be analyzed utilizing methods that range from statistical elaboration to content analysis, narrative analysis, grounded theory, discourse analysis etc. [53].

Against this background, and further to this study aim, a case study strategy has been adopted and framed by the auspices of a qualitative methodological approach. Highly compatible to qualitative studies, case study research refers to an appropriate strategy to investigate social phenomena as experienced in the real world [72]. Moreover, given the fact that our inquiry involves the analysis of non-numerical data, namely, a set of textual regulatory instruments, content analysis method has been selected. Content analysis refers to a method closely associated to qualitative studies enabling researchers to codify, categorize and then analyze words, themes and concepts embedded in large documentary sources $[29,73]$. In that way, it is facilitated the identification of hidden or underlying patterns thus permitting a deeper understanding of the research problem [74].

As mentioned before, ISO 26000 guidelines have been chosen as this study CSR paradigm and have been thoroughly reviewed to identify key social responsibility concepts and topics. The path for exploring and analyzing our data can be viewed by Figure 1 and is further explained below.

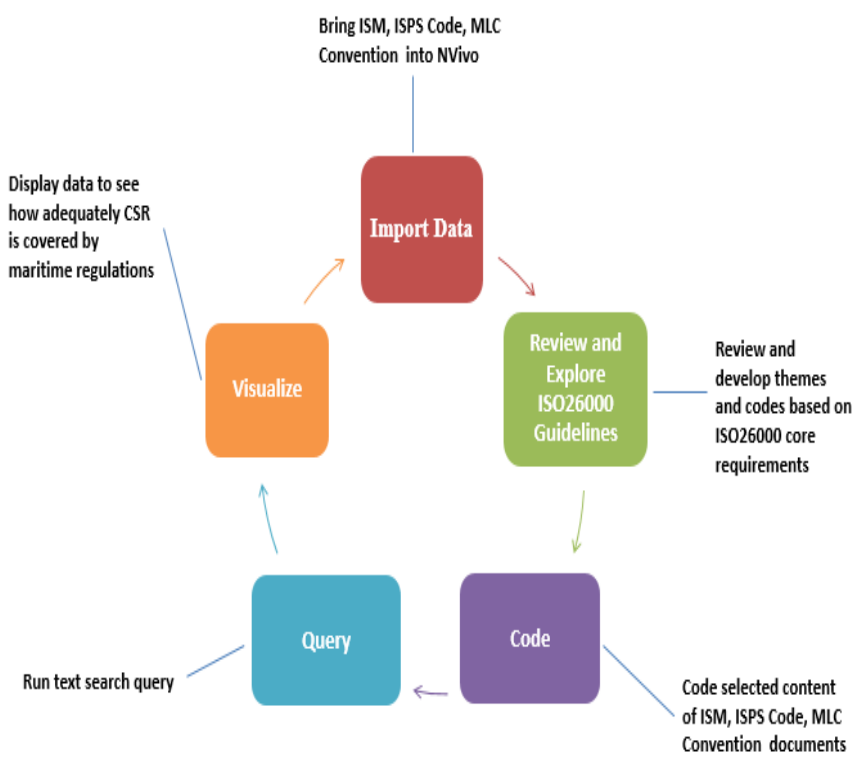

Figure 1. Content analysis execution logic

Initially, analysis commenced by inserting keywords into the search query function and carefully analyzing the context of each paragraph to originate words and key phrases most frequently appear and also encompassing key CSR meanings. Thereafter, gathered keywords were categorized under the seven core thematic areas of ISO 26000 (Figure 2) resulting to a total of 163 nodes and were assigned in their respective themes. Next, applicability of identified CSR nodes was attempted across the content of our study sources, namely the ISM, ISPS Code, and MLC 2006 Convention thus measuring the frequency with which each node appears. Then, identified references were saved into their corresponding nodes thus putting into consideration the number of regulatory sources in which they appear. At end, effectiveness of the maritime regime to address CSR issues was examined in its entirety but also individually for each regulatory source. NVivo qualitative software was employed to facilitate the content analysis process.

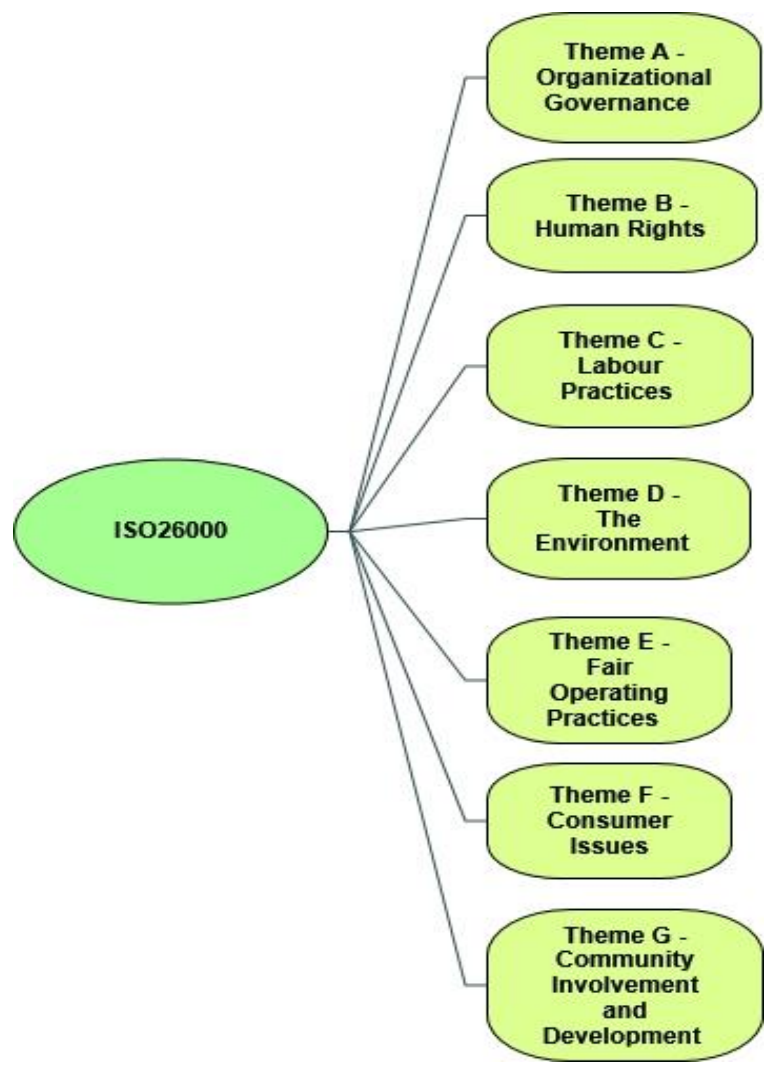

Figure 2. Principal content analysis themes / nodes

\section{RESULTS}

This section presents the results of the content analysis carried out. Similar to the study aim and arrangement of the methodology, results indicate to what extent has the selected maritime regulatory framework dealt with specific CSR subjects. In addition, we evaluated which of these identified subjects have the highest contribution in addressing CSR. Once again, and as has been already explained in the background section, it is briefly reiterated that criteria for selecting ISO 26000 as CSR paradigm was due to its multisectoral applicability, comprehensive coverage of social responsibility principles and subjects, along with its advisory and non for certification character. In addition, delimitation of the case study field in the ISM Code, the ISPS Code and MLC 2006 context was guided by this literature review, which established the great versatility of these regulations, along with the wide range of social, economic, environmental, safety and security issues they seek to address. And more importantly, such pursuit is sought through a process making, culture creation and human element centered approach, thus affirming compatibility of this regulatory framework with principal CSR aspects. Hence, that was the reason that other important, but one-sided and technically focused shipping regulations, were judged to be out of this pursuit and study scope. To get an overview, Table 1 shows the percentage of coverage for the 50 most rated nodes within their respective CSR theme. 
Table 1. Summary of 50 most frequent CSR nodes in the maritime regime

\begin{tabular}{|c|c|}
\hline Node & \begin{tabular}{|c|} 
Percentage \\
coverage
\end{tabular} \\
\hline Theme B Human Rights\Human rights & $9.87 \%$ \\
\hline Theme B Human Rights $\backslash$ Security & $9.87 \%$ \\
\hline Theme C Labour Practices\Health and Safety & $4.89 \%$ \\
\hline Theme C Labour Practices\Training & $1.76 \%$ \\
\hline Theme B Human Rights\Risk & $1.67 \%$ \\
\hline Theme A Organizational GovernancelCompliance & $1.32 \%$ \\
\hline Theme D The EnvironmentlEnvironment & $0.63 \%$ \\
\hline Theme B Human RightslEmployment opportunities & $0.54 \%$ \\
\hline Theme A Organizational GovernancelReview & $0.50 \%$ \\
\hline Theme D The Environment lNoise & $0.50 \%$ \\
\hline Theme C Labour Practices\Accident prevention & $0.49 \%$ \\
\hline Theme C Labour Practices\Physical & $0.48 \%$ \\
\hline $\begin{array}{c}\text { Theme A Organizational } \\
\text { GovernancelCommunication }\end{array}$ & $0.47 \%$ \\
\hline Theme A Organizational GovernancelPerformance & $0.45 \%$ \\
\hline Theme A Organizational GovernancelMonitoring & $0.45 \%$ \\
\hline $\begin{array}{c}\text { Theme A Organizational GovernancelManagement } \\
\text { system }\end{array}$ & $0.38 \%$ \\
\hline Theme B Human RightsiSocial protection & $0.34 \%$ \\
\hline Theme A Organizational GovernancelProcess & $0.33 \%$ \\
\hline Theme B Human Rights\Food & $0.30 \%$ \\
\hline Theme B Human Rights IWater & $0.29 \%$ \\
\hline Theme B Human Rights\Medical care & $0.24 \%$ \\
\hline Theme C Labour PracticeslWelfare & $0.23 \%$ \\
\hline Theme C Labour Practices\Committees & $0.21 \%$ \\
\hline Theme B Human Rights\Cultural & $0.20 \%$ \\
\hline Theme C Labour Practices\Representative & $0.20 \%$ \\
\hline Theme C Labour Practices $\backslash$ Stress & $0.20 \%$ \\
\hline $\begin{array}{c}\text { Theme C Labour Practices } \backslash \text { Personal protective } \\
\text { equipment }\end{array}$ & $0.18 \%$ \\
\hline Theme B Human Rights\Complaint & $0.17 \%$ \\
\hline Theme C Labour PracticeslSocial security & $0.16 \%$ \\
\hline Theme C Labour Practices $\backslash$ Wages & $0.16 \%$ \\
\hline Theme C Labour Practices\Mental & $0.15 \%$ \\
\hline Theme A Organizational GovernancelProcedure & $0.15 \%$ \\
\hline Theme C Labour Practices\Chemical & $0.14 \%$ \\
\hline Theme C Labour Practices\Living conditions & $0.12 \%$ \\
\hline Theme C Labour Practices\Biological & $0.11 \%$ \\
\hline Theme C Labour PracticeslNational law & $0.10 \%$ \\
\hline Theme B Human Rights\Physical and mental & $0.09 \%$ \\
\hline Theme D The EnvironmentlPollution prevention & $0.09 \%$ \\
\hline Theme C Labour Practices\Hours of work or rest & $0.07 \%$ \\
\hline Theme C Labour Practices\Illness & $0.06 \%$ \\
\hline Theme D The Environment $\mid$ Toxic & $0.06 \%$ \\
\hline Theme B Human RightslNatural resources & $0.06 \%$ \\
\hline Theme B Human RightslSickness & $0.06 \%$ \\
\hline Theme C Labour PracticeslSafety and health policy & $0.06 \%$ \\
\hline $\begin{array}{c}\text { Theme C Labour Practices } \backslash \text { Reporting and } \\
\text { investigation }\end{array}$ & $0.05 \%$ \\
\hline Theme C Labour Practices\Tripartite & $0.05 \%$ \\
\hline Theme C Labour PracticeslEmergency procedures & $0.05 \%$ \\
\hline $\begin{array}{l}\text { Theme B Human Rights\Employment and social } \\
\text { rights }\end{array}$ & $0.05 \%$ \\
\hline
\end{tabular}

\begin{tabular}{c|c|} 
Theme E Fair Operating Practices $\backslash$ Suppliers & $0.04 \%$ \\
\hline Theme B Human Rights Personal data & $0.04 \%$
\end{tabular}

Source: Authors' calculations.

\subsection{Corporate Social Responsibility on the grounds of the ISM Code}

The ISM Code was the first regulation to be explored. In its entirety, results indicated that 36 out of the 163 originally developed CSR nodes found to be extensively covered by the ISM Code content. However, results highlighted that no reference was made to 3 out of the 7 formulated social responsibility themes. Thus, the health and safety topic is rated as the most cited $(11.52 \%)$, while subjects such as worker representative, resilience, mental and noise issues displayed a small appearance in the ISM Code text with average rates being below $0.4 \%$. Moreover, topics such as Management system (4.4\%), Regulatory compliance (3.6\%), Risk management (2.1\%), Training (1.8\%), Environment protection $(1.6 \%)$, Procedures and processes $(0.8 \%)$ and Pollution prevention $(0.88 \%)$ cited broadly into the ISM Code text body. Figure 3 shows the 20, out of 163, most rated social responsibility themes taken care of by the ISM Code.

\section{CSR Themes Coverage (\%) in ISM Code}

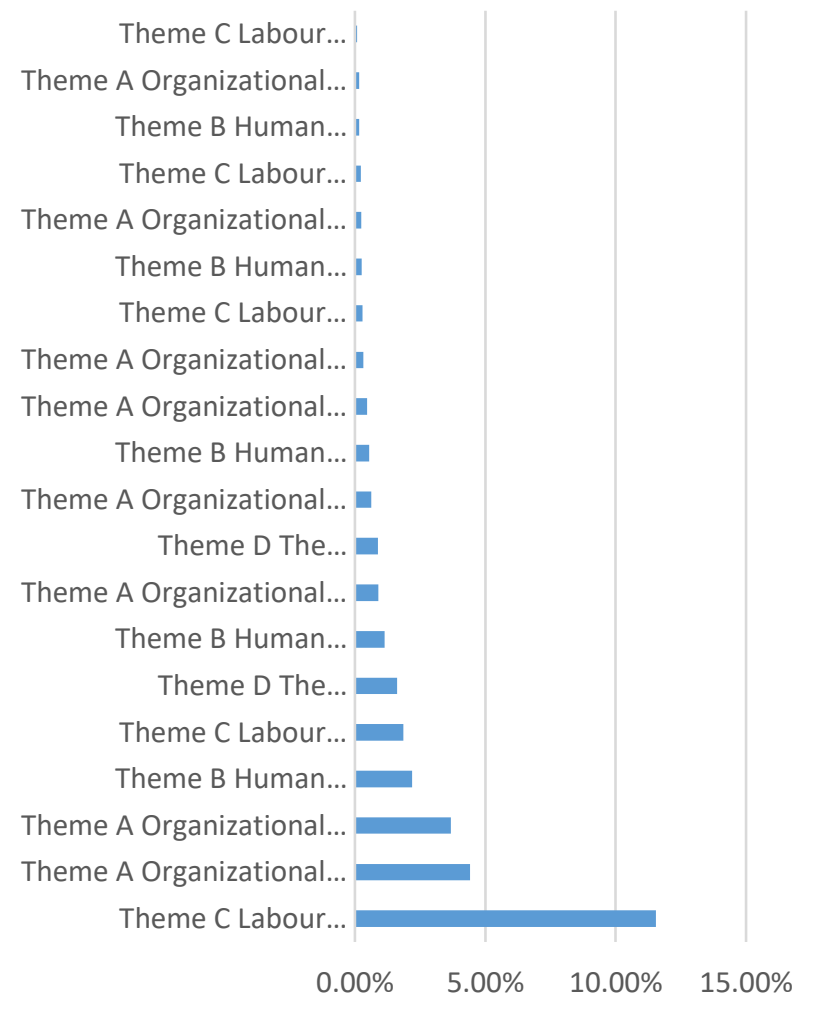

Figure 3. ISO26000 nodes percentage coverage in the ISM Code

It should be noted here that appearance of those topics was something that we expected since, as per initial review, found to be compatible with the ISM Code scope, namely, to provide a framework for companies in order to achieve safe ship operations and prevent marine pollution. Consequently, would say the ISM Code adequately deals with issues that fall within the thematic units of Organizational Governance, Human Rights, Labour Practices and The Environment. On the 
contrary, findings showed that core social responsibility subjects related to Fair Operating Practices, Consumer Issues and Community Involvement and Development found to have no identification and coherence with the ISM Code. Further to that, important aspects of ISO 26000 guidelines, such as Economic development, Fair operating practices, Consumer, Community involvement Stakeholder involvement, Women empowerment and Community development have been left untouched by the ISM Code. Delving further into the results, we found that the ISM Code covers a few noteworthy aspects of Human rights and Labour practices themes, such as, Education (0.25\%), Hours of work or rest $(0.09 \%)$, Accident prevention $(0.04 \%)$ and Emergency procedures $(0.09 \%)$. However, it leaves aside significant core concepts of themes such as, Decent employment, Religion, Social protection, Stress, Living, conditions and Fair terms of employment.

\subsection{Corporate social responsibility disclosure from an ISPS code perspective}

As per results, 42, out of the 163 developed nodes, found a place in the ISPS Code textual requirements. Similar to ISM Code, the most common subjects the ISPS Code deals with fall under the ISO 26000 thematic areas of Organizational Governance, Human Rights, Labour Practices and The Environment. Similar to ISM Code, subjects related to Fair Operating Practices, Consumer Issues and Community Involvement and Development remain mainly untouched by the ISPS Code. Therefore, inclusion of themes such as, Suppliers management, Stakeholder involvement and Service quality found to be negligible. Figure 4 presents content analysis results, as a percentage of the 20 most frequently cited CSR nodes within the ISPS Code.

\section{CSR Themes Coverage (\%) in ISPS Code}

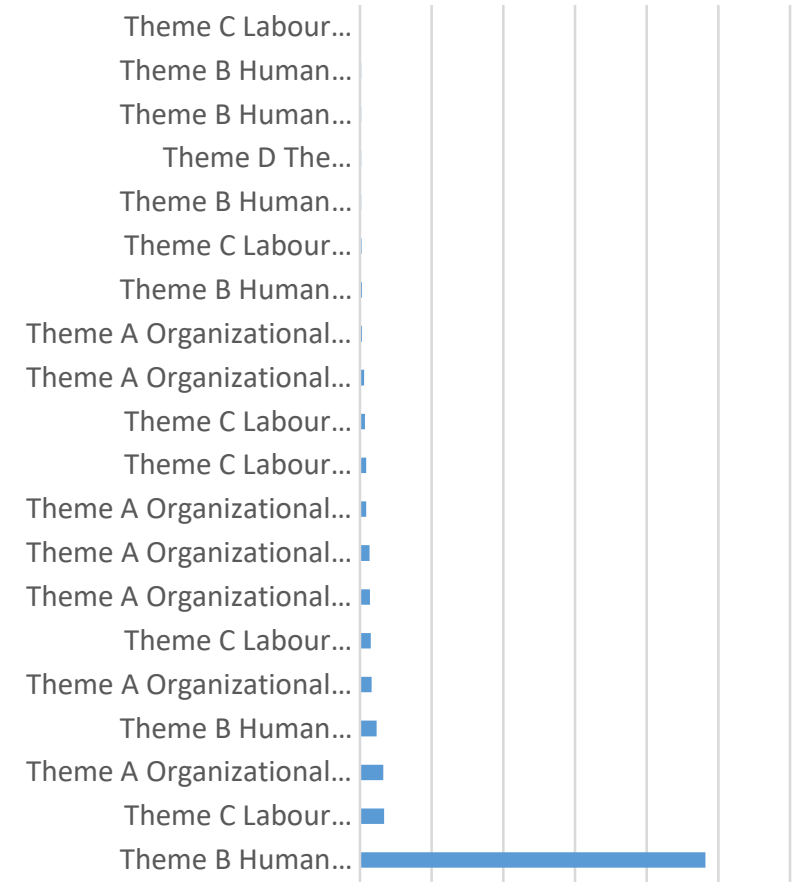

0.00\%5.00\% $0.00 \% 5.00 \% 0.00 \% 5.00 \% 0.00 \%$

Figure 4. ISO26000 nodes percentage coverage in the ISPS Code
From the aforementioned Figure 4, it is apparent that security subjects justifiably dominate the largest area in this regulation with an overall of ratio $24.11 \%$. Thus, topics such as, Training (1.68\%), Compliance (1.64\%), Risk (1.15\%) and Health and Safety $(0.75 \%)$, within security range, are high in the list of the most rated themes. This is an encouraging feature in safeguarding human rights, as security of every business and social activity refer to integral subjects of ISO 26000 social responsibility standard. Analyzing further the content of the ISPS Code we find that the security topic has been adequately covered by the various circulars and guidelines that supplement the ISPS Code and provide best management practices to shipping companies to deal with terrorism, smuggling, high jacking and piracy at sea. In addition, another topical to CSR concept issue that of personal data protection and cyber security threats, found to be treated quite comprehensively by the ISPS Code. To sum up, the ISPS Code turned out to place a unilateral emphasis on security subjects, yet without coverage of other broader aspects of social responsibility concept, as raised by ISO 26000. This is affirmed by viewing Figure 4, where negligible inclusion of the rest of the social responsibility nodes is ascertained. Thus, we would say that, on the whole, the ISPS Code addresses slightly broader CSR issues concentrating, mainly, in the subject of security of merchant seamen.

\subsection{Achieving CSR through the MLC 2006 convention}

The Maritime Labour Convention (MLC) 2006 is the third international convention explored by this study. Recalling its scope, it was introduced by the International Labor Organization in an effort to unite the hitherto fragmentary maritime legislation related to seafarer's rights, working and living conditions, along with specifying several shipowners and seafarers contractual obligations. Content analysis results showed that the MLC 2006 included 100, of the 163 developed, nodes within its body text. These findings fall in the thematic areas of Organizational Governance, Human Rights, Labour Practices and The Environment. In fact, issues such as, Health and Safety $(6.96 \%)$, Risk (1.98\%), Training (1.8\%), Employment opportunities $(0.97 \%)$, Social responsibility $(0.94 \%)$, Noise $(0.94 \%)$, Accident prevention $(0.92 \%)$ and Environment $(0.88 \%)$ are amongst the most frequently cited subjects within the MLC 2006 Convention. Reflective of the empirical evidence is Figure 5 below, which summarizes the nodes percentage coverage within the MLC 2006 Convention. Great importance is attached to issues such as, Wages $(0.29 \%)$, Mental issues $(0.28 \%)$, Cultural issues $(0.25 \%)$, Physical and mental stress $(0.16 \%)$, Employment and social rights $(0.09 \%)$, Collective bargaining agreement $(0.05 \%)$, Child labour $(0.02 \%)$ and Forced labour $(0.01 \%)$. Contrasting those to former findings, it is worth commenting that MLC 2006 originalizes and addresses issues than none of the ISM and ISPS Code had encountered.

Obviously, it is noteworthy that the MLC 2006 Convention also covers social responsibility issues contained in the thematic units of the Fair Operating Practices, Consumer Issues and Community Involvement and Development, areas which the ISM and ISPS Code have left intact. Specifically, the MLC 2006 provides guidance on crucial CSR issues such as, Human rights $(0.04 \%)$, Freedom of association $(0.04 \%)$, Complaints and dispute resolution $(0.01 \%)$, Fair completion $(0.01 \%)$, Finding employment $(0.01 \%)$, Quality standards in ship management $(0.01 \%)$ and Contractual arrangements 
between seafarers and ship-owners (0.01\%). However, we must not overlook the fact that the MLC 2006 does not provide coverage for CSR themes related to Society expectations, Fair competition, Consumer issuers, Sustainability and Economic development, which as per ISO 26000, represent essential elements of social responsibility.

\section{CSR Themes Coverage (\%) in MLC Convention}

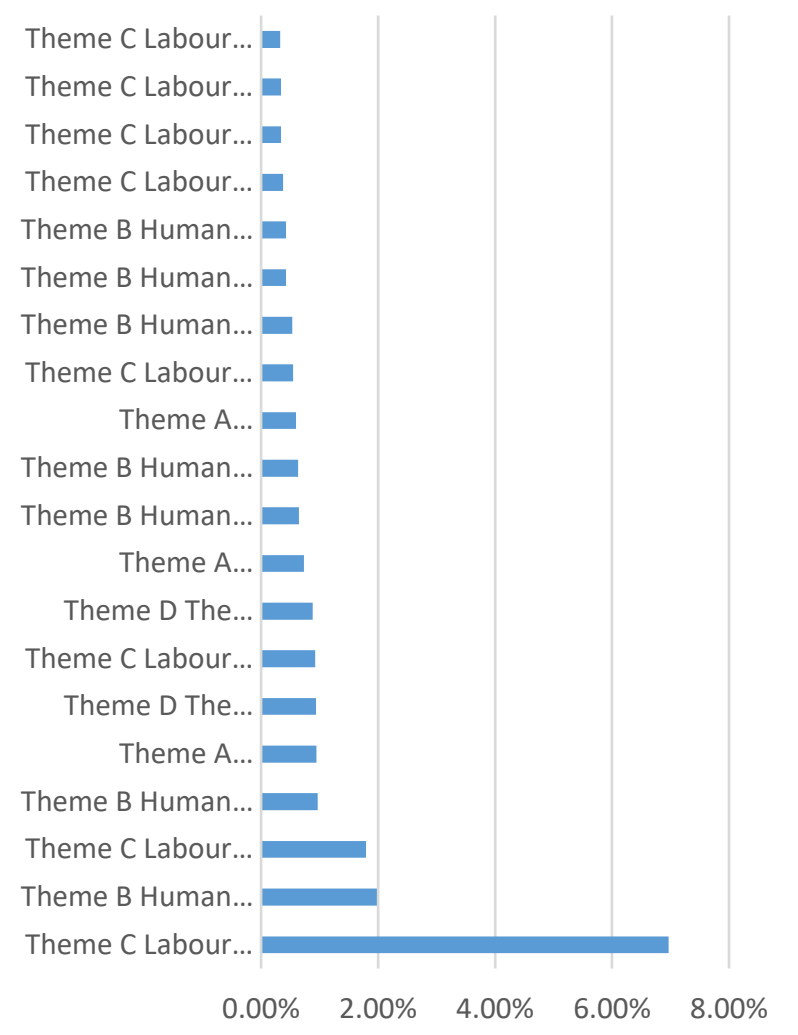

Figure 5. ISO26000 nodes percentage coverage in the MLC Convention

\section{DISCUSSION}

The empirical findings provided evidence according to which, the maritime regulatory regime appeared to satisfactorily cover a wide range of social responsibility issues laying in the area of human rights, security, health and safety, training, risk, regulatory compliance, environmental protection, employment opportunities, complaint resolution, collective bargaining agreement, discrimination, freedom of association, fair terms of employment, working practices, and harmful substances management. Unsurprisingly, this finding found to be congruent with outcomes from the studies of Parsons and Allen [75], Kuronen and Tapaninen [76] and Ducruet [77], which indicated the long ago developed tradition and consistency on behalf of the shipping industry in dealing proactively with maritime safety and environmental protection compliance issues. Such a fact corroborates also with the findings of the studies by Drobetz et al. [78] and Lam and Lim [79], who suggested that CSR in shipping is mainly understood and associated with the effort to comply with environmental and safety regulations, rather than formulating a socially responsible profile $[78,79]$. On the other hand, there is also some controversy, which argues that in recent years, and following the example of land industries, the maritime sector has widened its perception and adoption of CSR issues related to stakeholder management, corporate governance, employee relationships, ethics and transparency [39, 41, 80]. Nevertheless, and further to study findings, it is assumed that the negligible inclusion by the maritime regulatory regime of subjects such as, Fair operating practices, Consumers and Community involvement and development underlines the somewhat anachronistic and lack of regulatory approach to current CSR.

It should be acknowledged at this point that the identified, by this study, shortcoming of the maritime regulatory regime to address core CSR issues would have been, possibly, more obvious had it not been for the introduction of the later MLC, 2006, Convention. As a matter of fact, the MLC, 2006, Convention, increased significantly coverage of several CSR topics related to labour practices, contractual rights, conditions of employment, social welfare and living matters of seafarers, which until then, had remained fragmented or even untouched by statutory maritime regulations. However, even so, and similar to ISM Code, it should be admitted that the MLC, 2006, Convention, in its entirety, was not proved enough to provide coverage on fundamental issues of social responsibility, particularly, in the themes of Fair operating practices, Consumers and Community involvement and development.

Furthermore, trying to interpret the limited coverage of fundamental CSR terms by the selected maritime regulatory system, it would be interesting to correlate our findings to previous studies, which highlight the element of 'volunteering' in the perception of corporate social responsibility by the shipping industry [43, 44]. Similarly, studies by Jasmi and Fernando [81], Fasoulis and Kurt [39] and Yuen and Lim [82] suggested that shipping companies mostly viewed compliance with statutory maritime legislation, improvement of environmental and safety performance and reduction in accidents rates, as non-significant motives to adopt a CSR mentality and related principles $[26,81,82]$. This fact, coupled to the relatively recent shift and diffusion of CSR mindset in the shipping industry, turned out consistent with this study finding, namely, the limited use of advanced CSR topics by the maritime regime. Thus, while its popularity has decreased over the years, maritime statutory legislation seemed no to have taken into consideration deeper CSR aspects, which are still considered as something voluntary and of a non-statutory nature.

Last but not least, results showed that the selected regime makes no reference to sustainable development. Obviously, the maritime regulatory regime was not found to urge and require maritime operators to address sustainable development pillars through establishment of integrated economic, environmental and social corporate objectives. Evidently, promulgating sustainable development at policy level does not form part of ISM, ISPS and MLC 2006 requirements for company policy objectives. To be fair though, this should not be credited as a pure omission since many of the elements of sustainable development are already covered by IMO strategic plan committed to drive shipping into a sustainable development path [40, 62, 83].

Further to the above results and discussion, Figure 6 depicts the rate of coverage of ISO 26000 subjects by the maritime regulatory regime. 


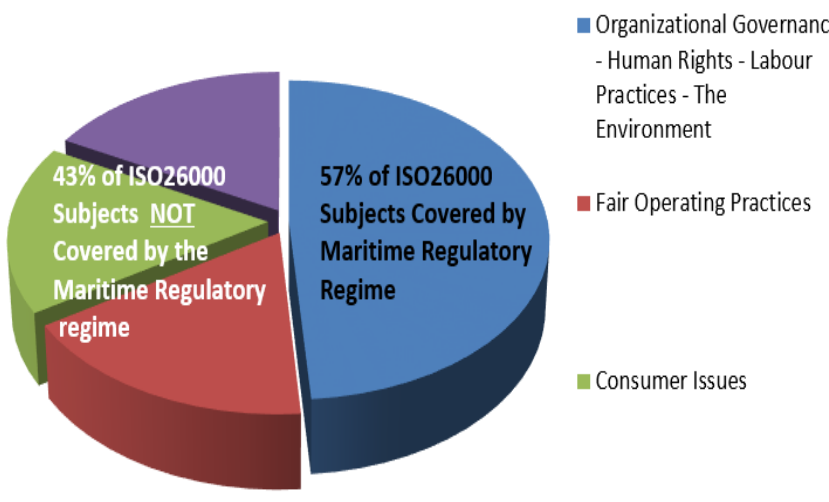

- Community Involvement and Development

Figure 6. Coverage of ISO 26000 core subjects by the maritime regulatory regime

\section{CONCLUSION}

The emerging practice of CSR, combined with the latest progresses in sustainable development requirements for the shipping industry, provided the rationale to study relevant challenges and configurations into the maritime regulatory regime. In particular, this paper departed from the concern that limited research was available to highlight whether the maritime regulatory regime can sufficiently address CSR issues for the maritime sector. Therefore, the aim of the study was to explore and uncover details on the effectiveness of maritime regulations to embrace core social responsibility issues. To achieve this, the maritime regulatory regime was delimited by the ISM and ISPS Codes and MLC, 2006, Convention and core themes and issues of ISO26000 standard were used as CSR benchmark. Relying on data collected through a qualitative research approach and adopted case study strategy and content analysis method, this study offered us the opportunity to get a complete picture of CSR themes in which the shipping regulatory system turns out to be effective, but also for those issues which it possibly lags behind.

In sum, key findings show that the percentage of CSR themes reflected into maritime regulatory framework is collectively higher than those topics that are not dealt with. Understanding findings and theoretical implications of this study can assist policy makers and regulators to better evaluate the state and framework of CSR implementation in the maritime industry and drive their future regulatory and policy actions to areas that require improvement. As discussed, due diligence must be given to specific CSR themes such as, Fair operating practices, Consumer issues and Community involvement and development, in which the maritime regulatory regime has significantly lagged behind, always speaking from a management model or system perspective. In addition, no report or incitement noticed on condition of sustainable development and the need to address CSR and sustainability from a management system perspective in shipping.

Further to the above, since sustainability placement is a core objective of ISO 26000, and amidst growing concern and focus of the global community to strengthen shipping industry contribution toward sustainable development, a relevant amendment to the existing regulatory framework could be effected to incorporate the visionary concept of sustainable development. Such initiative would boost even more shipping in the direction of CSR compliance with the core ISO 26000 objective, that of sustainable development. Moreover, at a time of great challenges and continuous transformations in the global policy and regulatory requirements, maritime regulators should realize that a mere compliance with the maritime regulatory framework does not prove sufficient to ensure the socially responsible operation of an enterprise. In turn, ISO 26000 standard proved to expand beyond statutory legislation and thus could be launched as an ideal model for organizations wishing to bridge the gap between the maritime regulatory regime and CSR themes thus leading to sustainable maritime development.

However, assumptions about the reasons behind the low score in specific CSR areas could be attributed to the fact that, in shipping, regulatory approach to CSR differs substantially than other industries. As noted, shipping still maintains a voluntary approach to CSR, with its implementation in the shipping industry being relatively recent. Hence, special attention needs to be paid by legislators on how they will introduce and implant corporate social responsibility in shipping, and especially, for the themes that this study highlighted as uncovered. As such, alerting shipping companies regarding ISO 26000 capability to add value to their operations and contribute to sustainable development, rather than reforming the maritime regime with the launching another mandatory CSR rule, might turn out to be a more persuasive tactic in diffusing CSR values.

There are some limitations to the present study and, hence, the findings should be interpreted with caution. Firstly, although a qualitative approach was appropriate for exploring CSR reflections within the maritime regime, the use of a sole methodology restricts the generalizability of the results. Thereby, a quantitative approach and methods is recommended to investigate practical management models of shipping companies and demonstrate actual state of CSR practices and mindset, with the aim to further educate on CSR issues and assist maritime actors in utilizing them to the benefit of sustainable development goals. Moreover, employing further methods such as, in depth interviews with industry experts, and combine them with quantitative study techniques, would provide a basis for a thorough comparison between CSR regulatory theory and practice in shipping. Second, notwithstanding the richness of the insight gained from CSR state examination in the selected regulatory regime, modification of selection criteria and broadening of its scope, would allow the inclusion of other regulatory sources that could potentially provide further insights and contribute to the completeness of the study. In addition, lifting such limitation presents ample opportunities for future research across the national legislation of Flag States, with such comparative analyses to provide additional acumens of CSR contextual peculiarities at regional level.

\section{REFERENCES}

[1] Kolk, A. (2016). The social responsibility of international business: From ethics and the environment to CSR and sustainable development. Journal of World Business, 51(1): 23-34. https://doi.org/10.1016/j.jwb.2015.08.010

[2] Poddar, A., Narula, S.A. (2019). A study of corporate social responsibility (CSR) and sustainable development 
goal (SDG) practices. Mandated Corporate Social Responsibility: Evidence from India, 85-94. https://doi.org/10.1007/978-3-030-24444-6_5

[3] Hák, T., Janouškova, S., Moldan, B., Dahl, A.L. (2018). Closing the sustainability gap: 30 years after "Our Common Future", society lacks meaningful stories and relevant indicators to make the right decisions and build public support. Ecological Indicators, 87: 193-195. https://doi.org/10.1016/j.ecolind.2017.12.017

[4] Imperatives, S. (1987). Report of the World Commission on Environment and Development: Our Common Future. Accessed Feb, 10. http://www.un-documents.net/wcedocf.htm.

[5] Toppinen, A., Mikkilä, M., Lähtinen, K. (2019). ISO 26000 in Corporate Sustainability Practices: A Case Study of the Forest and Energy Companies in Bioeconomy. In: Idowu S., Sitnikov C., Moratis L. (eds) ISO 26000 - A Standardized View on Corporate Social Responsibility. CSR, Sustainability, Ethics \& Governance. Springer, Cham. https://doi.org/10.1007/978-3-319-92651-3_7

[6] O’Neil, J. (2018). 'People, Planet, Profits' and Perception Politics: A Necessary Fourth (and Fifth) Bottom Line? Critiquing the Current Triple Bottom Line in the Australian Context. In: Crowther D., Seifi S., Moyeen A. (eds) The Goals of Sustainable Development. Approaches to Global Sustainability, Markets, and Governance. Springer, Singapore. https://doi.org/10.1007/978-981-10-5047-3_2

[7] Shehata, M.I., Omar, S.K. (2017). Energy efficiency in maritime transport. 18-th Annual General Assembly of the International Association of Maritime Universities, 12.

https://scholarworks.calstate.edu/downloads/9p290b37v \#page $=12$.

[8] Hussain, N., Rigoni, U., Orij, R.P. (2018). Corporate governance and sustainability performance: Analysis of triple bottom line performance. Journal of Business Ethics, 149(2): 411-432. https://doi.org/10.1007/s10551016-3099-5

[9] Agudelo, M.A.L., Jóhannsdóttir, L., Davídsdóttir, B. (2019). A literature review of the history and evolution of corporate social responsibility. International Journal of Corporate Social Responsibility, 4(1): 1. https://doi.org/10.1186/s40991-018-0039-y

[10] Ebner, D., Baumgartner, R.J. (2006). The relationship between sustainable development and corporate social responsibility. In Corporate Responsibility Research Conference, Queens University, Belfast Dublin. https://www.crrconference.org/Previous_conferences/do wnloads/2006ebnerbaumgartner.pdf.

[11] Roberts, R.W. (1992). Determinants of corporate social responsibility disclosure: An application of stakeholder theory. Accounting, Organizations and Society, 17(6): 595-612. https://doi.org/10.1016/0361-3682(92)90015$\mathrm{K}$

[12] Carroll, A.B. (1991). The pyramid of corporate social responsibility: Toward the moral management of organizational stakeholders. Business Horizons, 34(4): 39-48. https://doi.org/10.1016/0007-6813(91)90005-G

[13] Jamali, D. (2008). A stakeholder approach to corporate social responsibility: A fresh perspective into theory and practice. Journal of Business Ethics, 82(1): 213-231. https://doi.org/10.1007/s10551-007-9572-4
[14] Cochran, P.L. (2007). The evolution of corporate social responsibility. Business Horizons, 50(6): 449-454. https://doi.org/10.1016/j.bushor.2007.06.004

[15] Joyner, B.E., Payne, D. (2002). Evolution and implementation: A study of values, business ethics and corporate social responsibility. Journal of Business Ethics, 41(4): 297-311. https://doi.org/10.1023/A:1021237420663

[16] Tsalis, T.A., Malamateniou, K.E., Koulouriotis, D., Nikolaou, I.E. (2020). New challenges for corporate sustainability reporting: United Nations' 2030 Agenda for sustainable development and the sustainable development goals. Corporate Social Responsibility and Environmental Management, 27(4): 1617-1629. https://doi.org/10.1002/csr.1910

[17] Teck, T.S., Ayadurai, S., Chua, W. (2019). A contextual review on the evolution of corporate social responsibility. J. Mgmt. \& Sustainability, 9(2): 136. https://doi.org/10.5539/jms.v9n2p136

[18] Liczmańska-Kopcewicz, K., Mizera, K., Pypłacz, P. (2019). Corporate social responsibility and sustainable development for creating value for FMCG sector enterprises. Sustainability, 11(20): 5808 . https://doi.org/10.3390/su11205808

[19] Androniceanu, A. (2019). Social responsibility, an essential strategic option for a sustainable development in the field of bio-economy. Amfiteatru Economic, 21(52): 503-519. https://doi.org/10.24818/EA/2019/52/503

[20] Brooks, M.R., Faust, P. (2018). 50 Years of Review of Maritime Transport, 1968-2018: Reflecting on the Past, Exploring the Future (No. UNCTAD/DTL/2018/1). https:/unctad.org/system/files/officialdocument/dt12018d1_en.pdf.

[21] Sekimizu, K. (2012). A concept of a sustainable maritime transportation system. London: IMO. https://sustainabledevelopment.un.org/content/documen ts $/ 1163$ CONCEPT $\% 20$ OF $\% 20 \% 20$ SUSTAINABLE $\% 2$ 0MARITIME\%20TRANSPORT\%20SYSTEM.pdf.

[22] Mackinnon, T., Remke, S. (2016). The innovation inducement impact of environmental regulations on maritime transport: A literature review. International Journal of Innovation and Sustainable Development, 10(1):

69-86. https://doi.org/10.1504/IJISD.2016.073413

[23] Håvold, J.I., Oltedal, H.A. (2018). Culture and maritime safety. In Managing Maritime Safety, Routledge, 53-70. https://doi.org/10.4324/9780203712979

[24] Loftus, C.J., Quick, C.G., Marcus, C.D., Rosenthal, L., Dalziel, J., Pelot, R., Sherrard, T. (2019). Spotlight on safety: Why accidents are often not accidental. http://www.dieselduck.info/library/11\%20interesting/20 19.07-Spotlight\%20on\%20Safety.pdf.

[25] Puisa, R., Lin, L., Bolbot, V., Vassalos, D. (2018). Unravelling causal factors of maritime incidents and accidents. Safety Science, 110: 124-141. https://doi.org/10.1016/j.ssci.2018.08.001

[26] Fasoulis, I., Kurt, R.E. (2019). Determinants to the implementation of corporate social responsibility in the maritime industry: A quantitative study. Journal of International Maritime Safety, Environmental Affairs, and Shipping, 3(1-2): 10-20. https://doi.org/10.1080/25725084.2018.1563320

[27] Lim, K. (2017). The role of the International Maritime 
Organization in preventing the pollution of the world's oceans from ships and shipping. UN Chronicle, 54(2): 52-54. https://doi.org/10.18356/a4b7087f-en

[28] Dalaklis, D. (2017). Safety and Security in Shipping Operations. In: Visvikis I., Panayides P. (eds) Shipping Operations Management. WMU Studies in Maritime Affairs, vol 4. Springer, Cham https://doi.org/10.1007/978-3-319-62365-8 9

[29] Vaismoradi, M., Jones, J., Turunen, H., Snelgrove, S. (2016). Theme development in qualitative content analysis and thematic analysis. Journal of Nursing Education and Practice, 6(5). https://doi.org/10.5430/jnep.v6n5p100

[30] Wieslaw, T. (2012). Origins of ship safety requirements formulated by International Maritime Organization. Procedia Engineering, 45: 847-856. https://doi.org/10.1016/j.proeng.2012.08.249

[31] Psaraftis, H.N., Amboy, Psaraftis. (2019). Sustainable Shipping. Springer International Publishing. https://doi.org/10.1007/978-3-030-04330-8

[32] Darousos, E.F., Mejia, M.Q., Visvikis, I.D. (2019). Sustainability, maritime governance, and business performance in a self-regulated shipping industry: A study on the BIMCO Shipping KPI Standard. In the Routledge Handbook of Maritime Management, Routledge, pp. 98-108. https://doi.org/10.4324/9781315617138

[33] Wu, X., Zhang, L., Luo, M. (2019). Discerning sustainability approaches in shipping. Environment, Development and Sustainability, 22: 1-16. https://doi.org/10.1007/s10668-019-00419-z

[34] Chircop, A. (2019). The IMO Initial Strategy for the Reduction of GHGs from International Shipping: A Commentary. The International Journal of Marine and Coastal Law, 1(aop): 1-31 https://doi.org/10.1163/15718085-13431093

[35] Chircop, A., Shan, D. (2020). Governance of International Shipping in the Era of Decarbonisation: New Challenges for the IMO? In Maritime Law in Motion, Springer, Cham, pp. 97-113. https://doi.org/10.1007/978-3-030-31749-2 6

[36] International Maritime Organization (IMO). (2019). Strategy, planning and reform. Council 122nd Session, Agenda Item 3(a) https://wwwcdn.imo.org/localresources/en/MediaCentre /Documents/SDG_Strategy\%20and\%20planning.pdf.

[37] Akkan, E. (2019). CSR activities in maritime and shipping industries. In Cases on Corporate Social Responsibility and Contemporary Issues in Organizations, 276-298. https://doi.org/10.4018/978-15225-7715-7.ch016

[38] Froholdt, L.L. (Ed.). (2018). Corporate Social Responsibility in the Maritime Industry (Vol. 5). Springer. https://doi.org/10.1007/978-3-319-69143-5

[39] Fasoulis, I., Kurt, R.E. (2019). Reframing corporate social responsibility and sustainability in the aftermath of United Nations 2030 agenda: an empirical study into the tanker and dry bulk maritime sector. Journal of Marine and Island Cultures, 8(1): 61-82. https://doi.org/10.21463/jmic.2019.08.1.06

[40] Wu, X., Zhang, L., Luo, M. (2018). Current strategic planning for sustainability in international shipping. Environment, Development and Sustainability, 22: 17291747. https://doi.org/10.1007/s10668-018-00303-2
[41] Parviainen, T., Lehikoinen, A., Kuikka, S., Haapasaari, P. (2018). How can stakeholders promote environmental and social responsibility in the shipping industry? WMU Journal of Maritime Affairs, 17(1): 49-70. https://doi.org/10.1007/s13437-017-0134-z

[42] Yuen, K.F., Thai, V.V. (2017). Corporate social responsibility and service quality provision in shipping firms: financial synergies or trade-offs? Maritime Policy \& Management, 44(1): 131-146. https://doi.org/10.1080/03088839.2016.1237782

[43] Fasoulis, I., Kurt, R.E., Poutos, E.I. (2019). A quantitative study into perceptions and attitudes of corporate social responsibility and sustainability developments in international shipping. https://strathprints.strath.ac.uk/68903/.

[44] Lekakou, M., Theotokas, I., Stefanidaki, E. (2016). Corporate social responsibility in the shipping industry. In Research Handbook on Corporate Social Responsibility in Context. Edward Elgar Publishing. https://doi.org/10.4337/9781783474806

[45] Sethi, S.P., Rovenpor, J.L., Demir, M. (2017). Enhancing the quality of reporting in Corporate Social Responsibility guidance documents: The roles of ISO 26000, global reporting initiative and CSR-sustainability monitor. Business and Society Review, 122(2): 139-163. https://doi.org/10.1111/basr.12113

[46] Hemphill, T. (2013). The ISO 26000 guidance on social responsibility international standard: What are the business governance implications? Corporate Governance: The International Journal of Business in Society, 13(3): 305-317. https://doi.org/10.1108/CG-082011-0062

[47] Bowens, R. (2011). Understanding the ISO 26000 social responsibility standard and how it relates to and can be assessed alongside other standards. White Paper. Rutherford: SGS Inc. https://www.sgsgroup.fr//media/global/documents/white-papers/sgs-iso-26000white-paper-february-2011.pdf.

[48] Hahn, R. (2013). ISO 26000 and the standardization of strategic management processes for sustainability and corporate social responsibility. Business Strategy and the Environment, 22(7): 442-455. https://doi.org/10.1002/bse.1751

[49] Yuen, K.F., Wang, X., Wong, Y.D., Zhou, Q. (2017). Antecedents and outcomes of sustainable shipping practices: The integration of stakeholder and behavioural theories. Transportation Research Part E: Logistics and Transportation Review, 108: 18-35. https://doi.org/10.1016/j.tre.2017.10.002

[50] Zinenko, A., Rovira, M. R., Montiel, I. (2015). The fit of the social responsibility standard ISO 26000 within other CSR instruments. Sustainability Accounting, Management and Policy Journal, 6(4): 498-526. https://doi.org/10.1108/SAMPJ-05-2014-0032

[51] Aware, T.A. (2009). Guidance on social responsibility. http://www.yooyahcloud.com/MOSSCOMMUNICATI ONS/KIDRbc/ISO DIS 26000 Guidance on social re sponsibility.pdf.

[52] Balzarova, M., Castka, P. (2018). Social responsibility: Experts' viewpoints on adoption of the ISO 26000 standard. Corporate Social Responsibility and Environmental Management, 25(5): 819-824. https://doi.org/10.1002/csr.1497

[53] Saunders, M., Lewis, P.H.I.L.I.P., Thornhill, 
A.D.R.I.A.N. (2007). Research Methods. Business Students 4th edition Pearson Education Limited, England.

[54] Idowu, S.O., Sitnikov, C., Moratis, L. (2019). ISO 26000-A Standardised View of Corporate Social Responsibility Practices, Cases and Facts: An Introduction. In: Idowu S., Sitnikov C., Moratis L. (eds) ISO 26000 - A Standardized View on Corporate Social Responsibility. CSR, Sustainability, Ethics \& Governance. Springer, Cham. https://doi.org/10.1007/978-3-319-92651-3_1

[55] Tiba, S., van Rijnsoever, F.J., Hekkert, M.P. (2019). Firms with benefits: A systematic review of responsible entrepreneurship and corporate social responsibility literature. Corporate Social Responsibility and Environmental Management, 26(2): 265-284. https://doi.org/10.1002/csr.1682

[56] Panagiotakopoulos, P.D., Espinosa, A., Walker, J. (2016). Sustainability management: Insights from the viable system model. Journal of Cleaner Production, 113: 792806. https://doi.org/10.1016/j.jclepro.2015.11.035

[57] Fogarty, A.R. (2017). Merchant Shipping Legislation. Taylor \& \& Fancis. https://doi.org/10.4324/9781315232218

[58] Koval, V. (2019). Basic aspects of legal regulation of merchant shipping. Kazan University Law Review, 4(2): 114-122. https://doi.org/10.30729/2541-8823-2019-4-2$114-122$

[59] Karahalios, H. (2015). The Management of Maritime Regulations, Routledge. https://doi.org/10.4324/9781315751276

[60] Knudsen, O.F., Hassler, B. (2011). IMO legislation and its implementation: accident risk, vessel deficiencies and national administrative practices. Marine Policy, 35(2): 201-207. https://doi.org/10.1016/j.marpol.2010.09.006

[61] Chee, J.T. (2019). Shipping-into the future: Regulatory, technology, and operation. http://hdl.handle.net/10356/77719.

[62] Igwe, I.S., Ogbonnaya, E.A., Ajoko, T.J., Ombe, T.M. (2006). Experience from ISM Code as Implementation Model for the Maritime Labour Convention. European Journal of Engineering Research and Science, 4(5): 5057. http://dx.doi.org/10.24018/ejers.2019.4.5.1082

[63] Kivalov, S. (2019). ILO maritime labour convention 2006: The way towards ratification. Lex Portus, 4: 7-27. https://doi.org/10.26886/2524-101X.4.2019.1

[64] Kalaitzi, A.M. (2019). Internal audit in shipping

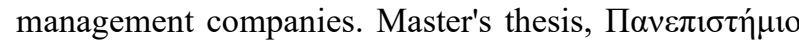
Пєıраı́́s. https://dione.lib.unipi.gr/xmlui/handle/unipi/12438.

[65] Lee, M.J. (2016). A study on the effectiveness of the ISM Code through a comparative analysis of ISM and PSC Data.

http://commons.wmu.se/all dissertations/543?utm sour ce $=$ commons.wmu.se $\% 2$ Fall_dissertations $\% 2 F 543 \& u t$ m_medium=PDF\&utm_campaign=PDFCoverPages.

[66] Gunawan, E., Zauhar, S., Sarwono, S., Bambang, S. (2019). The implementation of ship and port facility security policy based on ISPS code at PT Pelindo II (Cirebon branch). Journal of Management History, 25(1): 67-96. https://doi.org/10.1108/JMH-07-2018-0037

[67] Khoo, S.F. (2017). How has the shipping industry coped with the maritime labour convention? http://hdl.handle.net/10356/73011.

[68] Królikowski, A., Mrozowska, A., Wróbel, R. (2016).
Safety culture in the management system of safe exploitation of the ship and pollution prevention. Scientific Journal of Polish Naval Academy, 205(2): 4560. https://doi.org/10.5604/0860889X.1219969

[69] Rony, A.H., Kitada, M., Dalaklis, D., Ölçer, A.I., Ballini, F. (2019). Exploring the new policy framework of environmental performance management for shipping: A pilot study. WMU Journal of Maritime Affairs, 18(1): 124. https://doi.org/10.1007/s13437-019-00165-z

[70] Kumar, R. (2019). Research methodology: A step-bystep guide for beginners. Journal of Latinos and Education. https://doi.org/10.1080/15348431.2019.1661251

[71] Gregar, J. (1994). Research Design (Qualitative, Quantitative and Mixed Methods Approaches). Book published by SAGE Publications, 228. http://www.drbrambedkarcollege.ac.in/sites/default/files /Research-Design_Qualitative-Quantitative-and-MixedMethods-Approaches.pdf.

[72] Harrison, H., Birks, M., Franklin, R., Mills, J. (2017). Case study research: Foundations and methodological orientations. In Forum Qualitative Sozialforschung/Forum: Qualitative Social Research, 18(1). https://doi.org/10.17169/fqs-18.1.2655

[73] Graneheim, U.H., Lindgren, B.M., Lundman, B. (2017). Methodological challenges in qualitative content analysis: A discussion paper. Nurse Education Today, 56: 29-34. https://doi.org/10.1016/j.nedt.2017.06.002

[74] Erlingsson, C., Brysiewicz, P. (2017). A hands-on guide to doing content analysis. African Journal of Emergency Medicine, 7(3): 93-99. https://doi.org/10.1016/j.afjem.2017.08.001

[75] Parsons, J., Allen, C. (2018). The history of safety management. In Managing Maritime Safety, pp. 16-31. Routledge. https://doi.org/10.4324/9780203712979

[76] Kuronen, J., Tapaninen, U. (2010). Evaluation of maritime safety policy instruments. WMU Journal of Maritime $\quad$ Affairs, $\quad 9(1)$ : $45-61$. https://doi.org/10.1007/BF03195165

[77] Ducruet, C. (Ed.). (2015). Maritime Networks: Spatial Structures and Time Dynamics. Routledge. https://doi.org/10.4324/9781315692852

[78] Drobetz, W., Marinas, A., Merika, A., Tsionas, M.G. (2014). Corporate social responsibility disclosure: The case of international shipping. Transportation Research Part E: Logistics and Transportation Review, 71: 18-44. https://doi.org/10.1016/j.tre.2014.08.006

[79] Lam, J.S.L., Lim, J.M. (2016). Incorporating corporate social responsibility in strategic planning: case of shipoperating companies. International Journal of Shipping and Transport Logistics, 8(3): 273-293. https://doi.org/10.1504/IJSTL.2016.076258

[80] Donner, P., Johansson, T. (2018). Sulphur Directive, Short Sea Shipping and Corporate Social Responsibility in a EU Context. In: Froholdt L. (eds) Corporate Social Responsibility in the Maritime Industry. WMU Studies in Maritime Affairs, vol 5. Springer, Cham. https://doi.org/10.1007/978-3-319-69143-5_9

[81] Jasmi, M.F.A., Fernando, Y. (2018). Drivers of maritime green supply chain management. Sustainable Cities and Society, 43: 366-383. https://doi.org/10.1016/j.scs.2018.09.001

[82] Yuen, K.F., Lim, J.M. (2016). Barriers to the implementation of strategic corporate social 
responsibility in shipping. The Asian Journal of Shipping and $\quad$ Logistics, 32(1): 49-57. https://doi.org/10.1016/j.ajsl.2016.03.006

[83] Yuen, K.F., Thai, V.V., Wong, Y.D. (2018). An investigation of shippers' satisfaction and behaviour towards corporate social responsibility in maritime transport. Transportation Research Part A: Policy and Practice, 116:

https://doi.org/10.1016/j.tra.2018.06.027 